\title{
Begrebsdannelsernes uomgængelige ødselhed
}

\author{
Bemærkninger til Per Aage Brandts efterskrift i \\ Georges Bataille: Den indre erfaring (Rhodos 1972)
}

I erkendelse af, at der er behov for at få klaret op, hvor der i Poetiks virksomhed ligger forskelle og hvor der ligger svagheder, har redaktionen besluttet at fremkomme med selvkritik pà forskellig vis, i artikler og i kritiske kommentarer. For mit eget vedkommende vil jeg senere gøre rede for den kritik, jeg mener bør rettes mod min bog Semiotik og dialektik (1971), specielt de sidste afsnit deri, en kritik som implicit til en vis grad ligger i 'Modsigelsens poetik' i dette nummer; Ralf Pittelkows artikel i næste nummer om 'Samfundsteori og tekstteori' er på samme måde til dels implicit selvkritik, hvortil kommer et afsnit med kritik af Per Aage Brandts artikel 'Noter om praksis'. Når et skrift af Per Aage Brandt er emne for det folgende er det bl.a. fordi hans skrifter kan antages at indtage en priviligeret plads $i$ læsernes bevidsthed for sả vidt angár den nyeste franske kritik og filosofi, der for nogle (ukorrekt) står som Poetiks centrale baggrund, men det er også fordi nogle af de forhold, som jeg onsker at kritisere, dér fremtræder mere markant end de fleste andre steder. Endelig er det naturligvis fordi jeg finder dette skrift - og i en række henseender andre af PAB's skrifter - kritisabelt. Kritikken angår således de kritiserede træk generelt der hvor de fremtræder hos PAB og hos andre. Denne kritik skal dog ikke tages som en absolut afvisning af PAB's skrifter eftersom der tydeligt nok kan hentes nogen frugtbar inspiration dér, ligesom det allerede er sket i flere tilfælde. Det er dog min opfattelse, at de ansatser og indsigter, der mảtte ligge i PAB's skrifter, sảdan som de fremtræder teoretisk set og pædagogisk set - er et langt ringere bidrag til litteraturforskningens og kritikkens (såvel som semiotikkens) udvikling end de kunne være, hvis PAB dels tog sine læsere mere alvorligt, dels tog den foreliggende - og af ham anvendte/misbrugte - forskning mere alvorligt (jeg tænker her specielt på Marx’ socialvidenskab).

Jeg vil kort formulere min kritik og derefter eksemplificere den. Det er min opfattelse, at PAB samtidig med at han lader formode, at han ser sin virksomhed $i$ en marxistisk begrebsmæssig sammenhæng, fundamentalt forvansker de begreber han foregiver at hente hos Marx. Det er muligt, at der i nogle tilfælde er tale om misforstảelser fra min side, i sả fald mả kritikken rettes mod en fremstillingsform, der gør misforståelsen mulig. I det omfang det er hensigten gennem fremstilling af begrebsmæssig erkendelse at oplyse læserne, må det anses for fejlagtigt ikke at formulere 
sin formodede erkendelse således, at det er muligt for læseren at tilegne sig den og/eller at kritisere den; det er efter min opfattelse forkert at hensætte læserne i en evindelig fortolkningsaktivitet. Det er muligt, at der fra PAB's side er tale om en kritik af det marxistiske begrebsapparat, i sà fald fremstår det ikke eksplicit og hvad der implicit kan hentes frem synes ikke at angå marxismen, men forvanskede udgaver af marxismen. De træk, som jeg vil rette kritikken imod, er altså: den uvederhæftige gengivelse af Marx (og 'marxismen') og fremstillingsformen, som udelukker kritik og diskussion.

Jeg vil ikke her begive mig ud i en generel kritik af alt, hvad PAB har skrevet, men koncentrere mig om et enkelt skrift, som er - omtrent - det senest offentliggiorte, og som opviser en række af de træk, som jeg her har antydet. Jeg afstår eksplicit på forhånd fra at inddrage alt i diskussionen.

Jeg understreger, at det naturligvis er muligt, og efter skrifterne at dømme endda sandsynligt, at den form for begrebsmæssig erkendelse, som jeg tilsigter og forventer af seriøse skribenter, blot - for PAB - er en form for borgerlig restriktiv, fornuftig, vidensakkumulerende og på enhver máde lattervækkende indskrænkning; hvis det er tilfældet - set fra PAB's synspunkt - så er kritikken ganske givet forfejlet, men sả er vort ærinde også forskelligt.

Det skrift, som jeg her vil kommentere, præsenteres på den ene side som et efterskrift til den Bataille-bog, som PAB har oversat til Rhodos, pá anden side som et bidrag til bearbejdelse af den problematik, som generelt angår forholdet mellem samfunds reale produktionsomstændigheder produktionsmåde - og de ideologiske og bevidsthedsmæssige forhold. Overvejelserne angår tilsyneladende $\mathrm{i}$ første omgang disse forhold, sådan som de fremtræder under den kapitalistiske produktionsmåde, for så vidt som det i høj grad er Marx' analyse af vareformen, der reflekteres over, men samtidig synes projektet dog at angå almene forhold, som antages at være uafhængige af hvilken produktionsmåde, der er på tale.

Den PAB'ske diskurs erklærer sig sả vidt jeg kan se for materialistisk, og de mange referencer til Marx lader formode, at det er den marx'ske materialisme, der er på tale. Denne bestemmes ganske vist forskelligt $i$ forskellige marxistiske traditioner, men jeg vil her fastholde dens historiske karakter, idet jeg henviser til, at Marx' styrende erkendelses-interesse var indsigten $\mathrm{i}$ specifikke historiske omstændigheder. For $\mathrm{mig}$ at se má eventuelle refleksioner over almene erkendelsesteoretiske spørgsmäl, der vedrører samfundsvidenskabelig erkendelse, sável som forsøg på formulering af til enhver tid forekommende samfundsforhold, gå igennem en tilegnelse af den marxske analyse af den kapitalistiske produktionsmåde for så vidt der sigtes mod et arbejde på marxistisk grundlag eller imod kritik af Marx.

Jeg går ud fra, at PAB forstår sig selv som og forsøger at arbejde som marxist. 


\section{8}

Det første punkt angår sondringen mellem hvad PAB med Bataille kalder "den begrænsede økonomi" og "den generelle økonomi". Eftersom PAB angiver, at "den generelle økonomi" i sin formulering kan forekomme 'metaforisk' i forhold til "den begrænsede økonomi" må vi gå ud fra, at den sidstnæunte er økonomien, således som den analyseres af Marx i hans forskellige bidrag til 'kritik af den politiske økonomi' (dvs. primært Grundrids, Til kritikken af den politiske okonomi og Kapitalen). PAB skelner mellem: "et sncevert begreb om økonomien (dens produktionsmádes struktur) og et vidt begreb om den samme økonomi" (understregningerne er PAB's, jeg vil gerne understrege ordet 'samme') (p. 318). Man stiller sig allerede her det spørgsmål om understregningerne skal antyde, at det først er den 'generelle økonomi', som virkelig er begrebslig, mens den snævre økonomi er og bliver snœever. I teksten fremtræder - så vidt jeg kan se - en tematik omkring modsætningen mellem det snævre, begrænsede, beherskede, fornuftige m.m. og på den anden side det generelle, overskridende, ubeherskede, lystige m.m., således at den sidstnæunte række vurderes positivt - som funderende den sociale forandrings mulighed (se p. 328). Under alle omstændigheder har PAB den 'generelle økonomi' som ærinde, samtidig med at hans viden om den økonomi, som Marx beskriver, fremtræder som stærkt begrænset.

Det problem, der ligger $i$ at benytte termen "økonomi" om noget som ikke er økonomi i samme forstand, som den hvori termen anvendes i den sammenhæng, hvorfra den er taget, gøres eksplicit; for så vidt viser skriftet en vis redelighed. Beklageligvis opløses den igen ved en implicit afvisning af problemet, en afvisning der formuleres i en metaforik hentet fra den borgerlige retsopfattelse - og den må enhver læser naturligvis tage afstand fra i denne sammenhæng:

Den humanistiske selvdisciplin er et aspekt af en økonomisk adfærd, og den kumulative spekulation, som er humanismens beherskede tænkning, er - under bæltestedet - et specifikt moment i en specifik økonomisk praksis. Begrebet økonomisk praksis, og her: begrebet produktionsmåde, synes her anvendt såkaldt metaforisk ("stjålent", "med urette"): [...] (318).

Jeg skal ikke her formulere almene regler for sådanne 'lån', som altid har spillet en væsentlig rolle $\mathfrak{i}$ videnskabens udvikling, men blot gøre opmærksom på, at den blotte afvisning af kritikken af 'metaforikken' ikke sikrer dens anvendelses relevans; under alle omstændigheder må den konkrete fremstilling være det emne, der tages stilling til. Omvendt bekræfter en lảnt sprogbrug ikke enhver snik-snak, at kalde et eller andet fænomen en 'økonomi' sikrer ingen erkendelse.

Et helt centralt punkt i de ræsonnementer, som PAB fremlægger tilsyneladende under tilslutning til Bataille, er forholdet mellem produk- 
tion og konsumtion, hvor det postuleres, at konsumtionen i en eller anden forstand overskrider produktionen. Ser vi efter hos Marx viser det sig, at det er væsentligt for ham at fastslà konsumtionens afhængighed af produktionen, ikke blot $\mathrm{i}$ den banale forstand, at produktionen er en forudsætning for konsumtionen, men mere præcist sådan, at konsumtionen er et moment $i$ produktionen, eller anderledes formuleret, at det er produktionens styring ud fra kapitalens værdiøgningsbehov, der sætter lønarbejdernes konsumtion som reproduktion af den arbejdskraft, der er en forudsætning for den fortsatte reproduktion af kapitalen:

Inden for grænserne af det absolut nødvendige er arbejderklassens individuelle konsumtion derfor en forvandling af de livsfornødenheder, kapitalen har afhændet mod at fả arbejdskraft til gengæld, tilbage til arbejdskraft, som kapitalen påny kan udbytte. Den er produktion og reproduktion af det produktionsmiddel, der er mest uundværligt af alle for kapitalisten, nemlig af arbejderen selv. Arbejderens individuelle konsumtion forbliver således et moment af kapitalens produktion og reproduktion, uanset om den foregår inden for eller uden for værkstedet, fabrikken, osv. [. . .] Det ændrer ikke ved sagen, at arbejderens individuelle konsumtion virkeliggøres for hans egen skyld og ikke for kapitalistens. (Kapitalen I, 811).

Hertil kunne nu konsumtions-teoretikeren bemærke, at der kun er tale om det absolut nødvendige forbrug; men her træder et forhold ind mellem den kapitalist, den pågældende arbejdskraft konsumeres af, og den kapitalist, der har produceret arbejderens livsfornødenheder, reproduktionsmidler. For arbejasgiveren bør konsumtionen naturligvis holdes på et minimum, ethvert krav om overskridelse af dette minimum, dvs. ethvert krav om forøget del i merværdien, må fremtræde som umảdeholdent. For den kapitalist, der producerer arbejderens livsfornødenheder er forholdet det omvendte: arbejdernes forbrug er en forudsætning for realiseringen af hans merværdi, et lystigt merforbrug er kun til hans fordel (jvf. her Kapitalen II, kap. 1, f.eks. omkring side 76-77)). Noget andet er da kapitalisternes forbrug eller konsumtion. Her taler/skriver PAB om "kapitalejerens uhæmmede luksus, private og hellige konsumtion". (320). Hvor luksuriøst kapitalisten konsumerer, må afhænge af, hvor stort et behov, der af hans kapitals placering i den samlede samfundsmæssige proces sættes for forøgelse af produktionsapparatet, altså for investering og altså ikke luksusforbrug. Dette skifter med ændringerne i den samlede samfundsmæssige proces. Og det kan næppe være indiviuluelle kapitalisters luksus-forbrug, der fremtræder som overskridelse. Angående ekspanderende forbrug og ekspanderende produktion kan der givetvis af mere kompetente siges meget (f.eks. om militæret som aftager af overproduktion), men det anforte skulle være tilstrækkeligt til at problematisere konsumtionens stilling i den PAB'ske teori: 
Den væsentlige pointe, som Marx her klart fastholder, men andetsteds ikke ganske gennemfører, er denne, at konsumtionen omdanner rigdommene til voerdier, den producerer hellighed. (321) Mennesket vender tilbage til sig selv efter produktion og distribution, altsá gennem disse faser i økonomiens proces, $i$ konsumtionen - økonomiens asociale moment. (smst.).

For at se disse citaters strategiske placering, má vi anføre et tidligere sted: En økonomi er i sit videre begreb ikke slet og ret en struktureret udøvelse af "arbejde" ("handling", "projekt"). Arbejdet er en væremáde, som er forudsætningen for en produktion overhovedet, altså en fundamental væremåde, men ikke den eneste økonomisk relevante. Hvis arbejdet alene definerede økonomien, ville ophobningen og til nød den produktive konsumtion være økonomiens virkelighed. [. . .] Bataille betoner, at intet samfund i praksis holder sig til produktion og produktiv konsumtion alene: ethvert samfund ødsler." (318-9)

Man má her for det første spørge, hvad det er der polemiseres imod: hvad er det for en 'økonomi' (der angives som 'snæver'), der lader arbejdet alene definere økonomien? Og som ville lade 'ophobningen' og 'til nød den produktive konsumtion' være 'økonomiens virkelighed'? Hvad er i øvrigt meningen med 'til nød' her? Tilsyneladende opstilles her et ejendommeligt valg: mellem på den ene side den netop beskrevne 'snævre økonomi', som næppe nogen vil kendes ved, og på den anden side teorien om konsumtionen som overskridende produktionsmåden. Det er et falsk alternativ. Den konsumtion, som realiserer merværdien og reproducerer arbejdskraften er indkalkuleret i kapitalens bevægelse, konsumtionen som sådan er på ingen mảde asocial (men den enkel te kapitalists umádeholdne forbrug kan naturligvis være destruktivt, blot kun for ham selv som kapitalist). I øvrigt fremtræder PAB's behandling af disse spørgsmål som en sammenblanding af bestemmelser, der specifikt angår den kapitalistiske produktionsmåde, og almene bestemmelser ('hvis arbejdet alene definerer økonomien'), et træk som præger en stor del af hans brug af Marx' analyser.

På dette sted indføres også betegnelsen 'udsættelse', som spiller en meget stor rolle i ræsonnementerne (eller i skriftet, at tale om raison er formentlig et tilbagefald $i$ en borgerlig normativitet):

Arbejdet udscetter den ubegrænsede fortæring til senere (318).

Er det 'arbejdet som sådant', der her er tale om? Og hvad er det for en 'ubegrænset fortæring', der er tale om? Det er måske vareproduktion, der er på tale, altså det forhold, at produktet fremstilles med henblik på opfyldelse af andres behov, mens de egne behov opfyldes gennem 
konsumption af andres produkter, sáledes at markedet og udvekslingen træder ind mellem produktion og konsumtion. Men i sả fald er det ikke 'arbejdet', der 'udsætter'. Det kan også være, at det er en generel bemærkning, at altsả altid arbejdet - uanset produktionsmảde - 'udsætter' fortæringen. I så fald må det bemærkes, at selv en eksistens fra hảnden i munden (under paradisiske omstændigheder) sætter en tid mellem hảnden og munden. Hvordan man end læser sætningen, forbliver den uklar, og det er stadig en gåde, hvad det er for en 'ubegrænset fortæring', der udsættes.

$\mathrm{Nu}$ er det ikke på Kapitalen PAB støtter sig i sin teoretiseren over 'økonomiens asociale moment', men pá Grundrids, og det fremhæves tilmed, at Marx kun på dette sted har fat i det væsentlige, sảledes at alle argumenter hentet andetsteds fra på forhånd er ugyldiggiort - for så vidt angår diskussionen om Marx, og det er den, jeg fører her. Tilbage står således at studere Grundrids-citatet, som "klart fastholder [...] at konsumptionen omdanner rigdommene til værdier [...]" PAB plukker tre steder ud, som her skal gengives i deres kontekst:

3) Produktionen er ikke kun umiddelbart konsumption og konsumptionen ikke umiddelbart produktion; ej heller er produktionen kun middel for konsumptionen og konsumptionen formål for produktionen, d.v.s. at enhver leverer genstanden for den anden; produktionen leverer konsumptionens ydre genstand, konsumptionen leverer produktionens forestillede genstand; men enhver af disse er ikke kun umiddelbart den anden, eller kun formidlende den anden, men begge to frembringer, idet de fuldbyrdes, den anden; sig selv som den anden. Konsumptionen fuldbyrder først produktionsakten, idet den fuldender produktet som produkt, idet den opløser det, idet den fortærer den selvstændigt tingslige form ved det; idet den i kraft af behovet for gentagelse forøger det anlæg, der er udviklet i den første produktionsakt, til færdighed; den er altså ikke kun den afsluttende akt, hvorigennem produktet bliver produkt, men også hvorigennem producenten bliver producent. På den anden side producerer produktionen konsumptionen, idet den skaber konsumptionens bestemte måde, og dermed, idet den skaber konsumptionens stimulus, selve konsumptionsevnen som behov (32-33).

Konsumptionen skaber produktionens tilskyndelse; den skaber også den genstand, der som málbestemmende er aktiv i produktionen. Nảr det er klart, at produktionen udvortes frembyder konsumptionens genstand, så er det derfor ligeså klart, at konsumptionen soetter produktionens genstand ideelt, som indvortes billede, som behov, som tilskyndelse og som formål. Den skaber produktionens genstande i endnu subjektiv form. Uden behov, ingen produktion. Men konsumptionen reproducerer behovet $(30-1)$. 
Konsumptionen som nødtørft, som behov, er selv et indvortes moment i den produktive aktivitet. Men denne aktivitet er udgangspunktet for realiseringen og derfor ogsa dennes dominerende moment, akten hvori hele processen forløber videre. Individet producerer en genstand og vender gennem konsumptionen af denne igen tilbage i sig selv, men som produktivt individ og sig selv reproducerende individ. Konsumptionen fremtræder altså som et moment i produktionen (33-4).

Det er på baggrund af disse citater PAB skriver:

Ifølge Marx følger menneskets befrielse nok - og dette er fundamentalt - af dets produktive aktivitet; men befrielsen er ikke direkte dets arbejde. Mennesket vender tilbage til sig selv efter produktion og distribution, altså gennem disse faser i okonomiens proces, $i$ konsumptionen - økonomiens asociale moment. Den væsentlige pointe, som Marx her klart fastholder [osv. se ovenfor].

På baggrund af de anførte citater at konkludere, at Marx 'klart fastholder' at 'konsumptionen omdanner rigdommene til værdier' forekommer sært. Det er for Marx vareproduktionen, altså produktionen af de produkter, som siden konsumeres, der skaber vardier. Kapitalen begynder sådan:

I de samfund, hvor den kapitalistiske produktionsmåde hersker, viser rigdommen sig som en "uhyre vareophobning" [. . .]

hvoraf det fremgår, at 'rigdom' er et alment begreb, som må angå brugsværdier, der produceres under alle omstændigheder; vcerdi-produktion i specifik forstand er derimod karakteristisk for vareproduktionen, som er dominerende med den kapitalistiske produktionsmåde. Hvad det vil sige, at konsumptionen 'omdanner rigdommene til værdier', er ikke til at se. Men man må formode, at det er den 'generelle økonomi', der her er på spil, således at 'værdi' her betyder noget andet end i marxistisk økonomi. Men selv under denne forudsætning forbliver det uklart, hvad det er Marx 'klart' skulle fastholde i de anførte passager. Når det derefter tilføjes, at det er 'denne værdi-lære', 'der udfoldes i Batailles arbejder', og at den 'sætter eksistensfilosofien ind i økonomien', sả kan det ikke undre at Marx træder noget i baggrunden. Ydermere skrives der kort efter om "at den spekulative dialektik på "àndens" (værdiproduktionens) område - kulturarvens forvaltning - er en ikke tilfældig egenskab ved den kapitalistiske produktionsmåde, hvis værdiudvikling den er." Her ser det ud til, at det er 'åndelige værdier', der produceres af konsumptionen, men hvordan "den spekulative dialektik på "åndens" område" kan blive "den kapitalistiske produktionsmådes værdiudvikling", det er stadig gådefuldt, bl.a. fordi det ikke meddeles, hvad "den spekulative dialektik" er for noget. Det er måske Hegels filosofi? I så fald forbliver det stadig uklart, hvad den - sådan som 
den her indføres - har at gøre med Marx' analyse. At Hegels dialektik har at gøre med Marx' analyse er ganske vist rigtigt nok, men der gives her - så vidt jeg kan se - ikke noget bidrag til at bestemme dette forhold.

Som nævnt er PAB's projekt øjensynlig generelt, idet det er bestemmelse af under alle omstændigheder gældende forhold, der sigtes mod. I denne henseende er PAB for så vidt i overensstemmelse med Marx' hensigt i indledningen til Grundrids. Dog kunne PAB have taget Marx' advarsler alvorligt:

Der findes bestemmelser, der er fælles for alle produktionstrin, og som af tænkningen fikseres som almene; men al produktions såkaldte almene betingelser er intet andet end disse abstrakte momenter, hvormed intet virkeligt historisk produktionstrin er begrebet (27).

Det er overhovedet karakteristisk, at PAB, selv hvor han inddrager bestemmelser, der angår en specifik produktionsmåde, hurtigt forlader det specifikke til fordel for opstillingen af almene 'modeller'; i dette efterskrift sker det f.eks. ved indoptagelsen af Marx' 'værdi-ligning' i en generel 'semiosis' (se nedenfor). Det er også karakteristisk, at overvejelserne over 'praksis' i almindelighed tager udgangspunkt i Althussers 'praksis-begreb', som bygger på den almene indledning om den politiske økonomis metode, som udgør anden del af indledningen til Grundrids, samt de almene bemærkninger om arbejdet i 5 . kapitel af Kapitalen, jeg vender tilbage til dette nedenfor.

Da Marx i 1859 udgav Til kritikken af den politiske okonomi skrev han i sit berømte forord (det, hvorfra de altid citerede bemærkninger om basis og overbygning stammer):

En almindelig indledning, som jeg havde gjort udkast til, udelader jeg, fordi enhver forudgriben af resultater, der først skal bevises, ved nærmere eftertanke synes mig at virke forstyrrende, og fordi den læser, der overhovedet vil følge mig, má beslutte sig til at stige opad fra enkelthederne til det almene (MEUS I, 354).

Fremgangsmåden $\mathrm{i}$ den overfor anførte kritik har for så vidt i princippet fulgt denne procedure, idet jeg indledte med at angive, hvordan Marx ser forholdet mellem produktion og konsumption under kapitalismen, for så siden at gøre opmærksom på, at også den generelle indledning i Grundrids ser produktionen som overgribende. Det skulle ikke være nødvendigt at fortsætte med dette punkt. Interesserede kan læse videre i Grundrids-indledningen, men det er meget sandsynligt, at den ikke giver meget mening, hvis ikke man har gjort sig den ulejlighed at 'stige opad fra enkelthederne til det almene' altså at sætte sig ind i Marx' analyse af den kapitalistiske produktionsmåde. Det kan i øvrigt allerede $\mathrm{i}$ denne forbindelse bemærkes, at netop det alment sigtende i PAB's projekt gør det vanskeligt at få øje på, 


\section{4}

hvad dets hensigt egentlig er, hvorfor og til hvem efterskriftet er skrevet.

Efter de almene betragtninger over konsumtionen som 'økonomiens asociale moment' søger PAB at "præcisere" den generelt økonomiske "værditeori" ved "sammenføring af visse semiologiske og marxistiske modeller" (324). Det er i forste omgang Marx' analyse af vare-formen, der inddrages i skikkelse af formlen for den simple værdiform:

$\mathrm{x}$ vare $\mathrm{A}=\mathrm{y}$ vare $\mathrm{B}$ :

20 alen lærred $=1$ frakke.

Herom skriver Marx:

To forskellige varer A og B, i vort eksempel lærred og frakke, spiller åbenbart her to forskellige roller. Lærredet udtrykker sin værdi i frakken, frakken tjener som materiale for dette værdiudtryk. [...] Værdien af den første vare [i eksemplet lærredet] er fremstillet som relativ værdi, eller befinder sig i relativ værdiform. Den anden vare [frakken] fungerer som ækvivalent, eller befinder sig i ækvivalentform. (Kapitalen I, 144).

Altså: frakken befinder sig i ækvivalentform, lærredet befinder sig i relativ værdiform, eller frakken fungerer som ækvivalent, lærredet er fremstillet som relativ værdi, frakken tjener som materiale for at udtrykke lærredets værdi. Dette bliver hos $\mathrm{PAB}$ til:

Frakken - ækvivalentformen - "udtrykker sig" gennem lærredet den relative værdiform. Den sidste form manifesterer vcerdi som brugsværdi (som udgør "det stoflige i rigdommen, hvordan dens samfundsmassige form end er"), den første form manifesterer vœerdi som bytteværdi (som udgør rigdommens "samfundsmæssige form", hvis stoflige bærer brugsværdien er). Værdiligningen, uanset om den betragtes i sin simple form eller i sin komplekse pengeform, udtrykker det fundamentale og konstituerende økonomiske skel mellem produktion og konsumption, mellem arbejdende, udscettende adfærd og fuldbyrdende ikke-længere-udsættende, konsumptiv adfærd; som princip for enhver bytning udtrykker ligningen ikke blot forholdet mellem to varer (det forhold, der gør to produkter til varer), men selve forudsætningen for denne bytning, lærredets udscettelse, som alene tillader fremstillingen af en lærredsfrakke: [...] Ligningen skal altså læses som en kanalisering af konsumption mod produktion (fra venstre mod højre) og samtidig som oprettelsen af en afstand fra produktion (højre) til konsumption (venstre) [. . .] Fra lærred til frakke forløber en vis tid, arbejdstid, udtrykt i lighedstegnet [...] Værdiligningen finder sin semiologiske modsvarighed i definitionen [...]

hest: uparrettået hovdyr. 
Og ligesom før ligger der "mere" i udtrykket til venstre end i udtrykket til højre. [...] Definitionens kolon repræsenterer en kanalisering af hestens betydning mod dens (fornuftige, retsmæssige, definerede) mening, en tænknings tid, tiden for en logisk operation, som bytter en term mod en samling egenskaber. [...] Det økonomiske og semiologiske forhold kan indskrives i en semiosis eller tegnfigur [osv osv] (325-6).

Læseren kan selv sammenligne, men nogle enkelte bemærkninger kan dog være på sin plads. Eftersom pointerne i Marx' analyse er uafhængige af, hvilke varer, der benyttes som eksempel, falder hele PAB's kommentar af sig selv sammen; vi kan blot udskifte lærred og frakke med f.eks. te og kaffe:

10 pund te $=40$ pund kaffe (Marx har det eksempel pả side 161).

Det forbliver pointen, at kaffen udtrykker teens værdi, men det bliver vanskeligt at fá kaffen til at være et forbrug af te plus arbejdskraft (jeg gætter, at det er sådan PAB's udlægning af lærred-frakke-eksemplet skal forstås). I øvrigt kunne Marx ligeságodt have brugt eksemplet

1 frakke $=20$ alen lærred

for så vidt angår de erkendelsesmæssige pointer. PAB făr desuden i sin formulering vendt om på forholdet, idet han lader frakken "udtrykke sig" gennem lærredet, omvendt: det er lærredets værdi, frakken tjener som udtryk for. Også selve formuleringen er uklar, som kan kan se det ved at sammenligne ("manifesterer værdi som brugsværdi", "manifesterer værdi som bytteværdi"). Som nævnt ovenfor opløser PAB det specifikke i vareformen til fordel for sine (og Batailles?) almene spekulationer over forholdet mellem produktion og konsumption. Pointen i sammenstillingen med definitionen er formentlig, at det er samme slags 'fornuft' og 'tvang', der resulterer $i$ på den ene side 'okonomiserende' produktion og "fornuftig, retsmæssig, definerende" tænkning (er det Marx Webers sammenstilling af Den protestantiske etik og kapitalismens and, der spøger et eller andet sted i kilderne?). Der er under ingen omstændigheder tale om begrebsmæssig erkendelse her, tværtimod er der tale om opløsning af Marx' begrebsmæssige erkendelse af det fundamentale træk i den kapitalistiske produktionsmåde: vareformen. Efter forskellige manipulationer med værdi-ligningen, definitionen og den omtalte 'semiosis' resumeres det centrale således:

Pointen er for Bataille, at okonomien sả at sige "lækker", der findes altså et moment - manifesteret $i$ ethvert samfund - , i hvilket den okonomiske socialitet direkte negeres, mens den mere eilior mindre identisk regenererer sig (herpå beror muligheden af ændring $i$ en socialite ts struktur) (328). 
Dette moment er formentlig det tidligere omtalte "økonomiens asociale moment": altså "konsumptionen", som vi nu har fảet placeret på venstre side af lighedstegnet i værdi-ligningen. Den revolutionære teori begynder at tage form. Men nu fremstilles en ny "iscenesættelse" (328), idet "praksis" introduceres. Det her indførte begreb om "praksis i almindelighed" har optrådt andetsteds og bør derfor tages op til behandling samlet (jvf. Ralf Pittelkow i Poetik 19), men jeg vil her blot komme med enkelte kommentarer. PAB skriver om det som

marxistisk teori [her henvises til Althusser, den utydelige formulering "marxistisk teori" i ubestemt form gør det uklart om det skal tages som alment marxistisk eller blot som en bestemt udformning af marxisme; men altså det drejer sig om det, som marxistisk teori] kalder en praksis, dvs. en overgang fra råmateriale gennem en transformation til produkt, og herfra (den ofte i tanken udeladte tragiske overgang) tilbage til første fase:

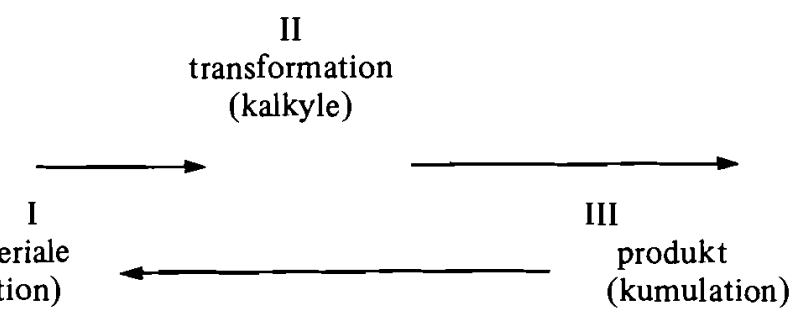
(konsumption) (kumulation)

Det er netop overgangen fra III til I, der herefter tillader en uddybet overvejelse over problemet om formidlingen mellem et samfunds økonomiske praksis i generel og vid forstand (politisk praksis, pædagogisk, juridisk, videnskabelig, æestetisk, religiøs osv). Denne formidling sker kort sagt gennem konsumptionens instans, og netop i kraft af loek-effekten [...] (328-9).

Til denne formulering kan bemærkes, at den ikke lader sig begribe: "en overgang fra råmateriale gennem en transformation til produkt, og herfra (den ofte i tanken udeladte "tragiske" overgang) tilbage til forste fase" "overgangen fra III til I [...] tillader en uddybet overvejelse". Det er klart nok hvad der ligger bag, nemlig den almene formulering af 'praksis' hos Althusser:

Enhver transformation (enhver praksis) forudsætter, som vi har set, transformationen af et rảmateriale til produkter ved hjælp af bestemte produktionsmidler. (Pour Marx 188).

Råmaterialerne i den teoretiske produktion kalder Althusser Generalitet I, produktet Generalitet III og produktionsmidlerne Generalitet II (de nærmere bestemmelser i forbindelse med det teoretiske arbejde skal jeg ikke her uddybe). Althusser kan her henvise til første del af kapitel 5 i Kapitalen I: 
Arbejdsprocessen skal derfor i første omgang betragtes uafhængigt af den særlige form, den antager under givne sociale betingelser. [...] Arbejdsprocessens elementære momenter er 1. den formålsrettede aktivitet eller arbejdet selv, 2 . arbejdsgenstanden og 3 . arbejdsmidlerne (arbejdsredskaberne) (302-3).

Hertil kan føjes arbejdets resultat, produktet. Althusser ser i sin formulering bort fra selve aktiviteten og holder sig til de størrelser, der er involveret. Det hele er ganske enkelt: arbejde består $i$ at bearbejde noget forud givet ved hjælp af nogle redskaber, sảledes at der kommer noget andet ud af det end det forud givne. Betimeligheden af at tale om "en overgang fra råmateriale til produkt" kan betvivles, ikke mindst da betegnelsen "overgang" igen benyttes om denne mysteriøse "overgang", der bestemmes som "herfra [dvs. fra produktet] tilbage til første fase", som oprindelig blev bestemt som rảmateriale; rảmaterialet er nu blevet en "fase", og der består et uudgrundeligt forhold mellem de to slags overgange, hvoraf den ene bestár $\mathrm{i}$ bearbejdelse af råmaterialet ved hjælp af redskaber. Man kan selvfølgelig her anføre Marx' ovenfor citerede betragtninger over produktionen som menneskets yderliggørelse og konsumtionen som det yderliggiorte menneskeværks 'venden tilbage' til mennesket selv. Bortset fra at det vil være at hænge sagen op på formuleringer hos Marx, som løsrives fra deres sammenhæng, så kan en sådan sammenstilling ikke tydeliggøre modellen, eftersom udgangspunktet var råmaterialet og ikke Mennesket eller sådan noget. Men det er - skal det understreges - måske ikke dette $\mathrm{PAB}$ gør.

Med denne 'praksis-model' forholder det sig på samme måde som med alt det øvrige, der postuleres at have at gøre med Marx: jo mere PAB skriver om det desto mindre fảr det at gøre med Marx' begrebsdannelser. "Produktionen $i$ almindelighed er en abstraktion, men en forstandig abstraktion, for så vidt som den virkelig fremhæver, fikserer det fælles og derfor sparer os for gentagelsen", skriver Marx $i$ indledningen til Grundrids. Så PAB ville umiddelbart - hvis han skulle ønske det - kunne hente støtte hos Marx i sine bestræbelser på at opstille teorier for dette og hint "i almindelighed", men abstraktionen er kun forstandig i det omfang den virkelig fremhæver det fælles. Og som Marx skriver - citeret ovenfor - må man for at forstå det almene under alle omstændigheder gøre sig den ulejlighed at sætte sig ind i det specifikke. Eftersom PAB at dømme efter dette efterskrift ikke har forstået Marx' analyse af vare-formen, så er der ikke meget håb om, at hans forsøg på at producere teori, der skulle angå "ethvert samfund", vil resultere i relevant begrebsmæssig erkendelse. Der er tværimod al mulig risiko for, at hans forsøg forbliver mere eller mindre mystificeret og mystificerende reproduktioner af forhåndenværende tankegods. Så meget desto mere beklageligt er det, at han ustandselig påberảber 


\section{8}

sig Marx som kilde til teorierne. Hvad der måtte være af potentiel erkendelse i PAB's arbejde sættes over styr, når-han som her øjensynlig hengiver sig til "begrebsdannelsernes uomgængelige odselhed" (317). Tilsyneladende er det intentionen at komme borgerlig tænkning til livs men resultatet er snarest, at det er Marx' tænkning og videnskabelige arbejde, der destrueres - for så vidt læserne ikke søger oplysning om marxismens politiske økonomi andetsteds. Uviljen mod begrebslig stringens formuleret som uvilje mod restriktiv borgerlig tænkning bliver $\mathrm{i}$ realiteten øjensynlig til uvilje mod at sætte sig ind i alternativ begrebsdannelse. Et fænomen som har ikke-tilfældige ligheder med den anarkistiske uvilje mod enhver form for organisation. Begge forhold fremtræder for mig som i sidste instans individualistisk og dermed borgerligt styrede afværgeforanstaltninger (dette er en meget generel bemærkning, hvis relevans jeg overlader til læserne at tage stilling til ud fra egne erfaringer).

I begyndelsen af efterskriftet skriver PAB - øjensynlig med tilslutning om Bataille:

[...] den tilbagetrukne erfaring, som Bataille kalder den indre erfaring, er altså en deltagelse, hvis sociale form er isolationen; der ligger heri ikke en "modsigelse" i blot verbal forstand, men en ægte materiel modsigelse (315).

Her kunne måske en analyse af grundlaget for den ødsle begrebsproduktion, som i realiteten er en begrebs-destruktion, tage sit udgangspunkt.

Det har ikke været hensigten her at foretage en analyse af de ideologiske formationer, som fremtræder i PAB's diskurs, kun at påvise, at der sker forvanskninger af Marx. Det har heller ikke været hensigten at søge at 'redde' de ansatser, der mảtte ligge til frugtbar erkendelse. Det arbejde er PAB selv den nærmeste til at tage op. 